another treatment option in the renal unit, though they are more complicated and expensive than the standard systems. So in which patients is the extra cost and complexity justified? It seems at present that bicarbonate dialysis should be reserved for those patients with unstable circulations, whether or not associated with diabetes or liver disease, and that further work is urgently needed to define other groups of patients who may benefit. Although very ill patients with acute renal failure might be expected to be particularly sensitive to the side effects of acetate dialysis, ${ }^{11}$ the advantages of bicarbonate dialysis for this group remain to be confirmed. ${ }^{37}$

Locum Consultant Nephrologist,

Martin A Mansell

St George's and St James's Hospitals,

London SW17 0QT

Consultant Physician,

A J WING

St Thomas's Hospital,

London SE1 7EH

${ }^{1}$ Mion CM, Hegstrom RM, Boen ST, Scribner BH. Substitution of sodium acetate for sodium bicarbonate in the bath fluid for hemodialysis. Trans Am Soc Artif Intern Organs 1964;10:110-3.

2 Novello A, Kelsch RC, Easterling RE. Acetate intolerance during hemodialysis. Clin Nephrol 1976;5:29-32.

3 Tolchin N, Roberts JL, Hayashi J, Lewis EJ. Metabolic consequences of high mass-transfer hemodialysis. Kidney Int 1977;11:366-78.

${ }^{4}$ Desch G, Oules R, Mion C, Descomps B, De Paulet AC. Plasma acetate levels during hemodialysis. Clin Chim Acta 1978;85:231-41.

${ }^{5}$ Mansell MA, Nunan TO, Laker MF, Boon NA, Wing AJ. Incidence and significance of rising blood acetate levels during hemodialysis. Clin Nephrol 1979;12:22-5.

${ }^{6}$ Kaiser BA, Potter DE, Bryant RE, Vreman HJ, Weiner MW. Acid-base changes and acetate metabolism during routine and high-efficiency hemodialysis in children. Kidney Int 1981;19:70-9.

7 Mansell MA, Crowther A, Laker MF, Wing AJ. The effect of hyperacetatemia on cardiac output during regular hemodialysis. Clin Nephrol $1982 ; 18: 130-4$

${ }^{8}$ Aizawa $Y$, Ohmori $T$, Imai $K$, Nara $Y$, Matsuoka $M$, Hirazawa $Y$. Depressant action of acetate upon the human cardiovascular system. Clin Nephrol 1977;8:477-80.

${ }^{9}$ Iseki K, Onoyama K, Maeda $\mathrm{T}$, et al. Comparison of hemodynamics induced by conventional acetate hemodialysis, bicarbonate hemodialysis and ultrafiltration. Clin Nephrol 1980;14:294-8.

10 Schohn DC, Klein S, Mitsuishi Y, Jahn HA. Correlation between plasma sodium acetate concentration and systemic vascular resistances. Proc Eur Dial Transplant Assoc $1981 ; 18: 160-8$

11 Vincent JL, Vanherweghem J-L, Degaute J-P, Berré J, Dufaye P, Kahn RJ. Acetate-induced myocardial depression during hemodialysis for acute renal failure. Kidney Int $1982 ; 22: 653-7$.

12 Gonzalez FM, Pearson JE, Garbus SB, Holbert RD. On the effects of acetate during hemodialysis. Trans Am Soc Artif Intern Organs 1974; $20: 169-74$

${ }^{13}$ Laker MF, Mansell MA. Measurement of acetate in aqueous solutions and plasma by gas phase chromatography using a porous polymer stationary phase. Ann Clin Biochem 1978;15:228-32.

${ }^{14}$ Skutches CL, Holroyde CP, Myers RN, Paul P, Reichard GA. Plasma acetate turnover and oxidation. 7 Clin Invest 1979;64:708-13.

15 Kveim M, Bredesen JE. A gas chromatographic method for determination of acetate levels in body fluids. Clin Chim Acta 1979;92:27-32.

16 Yamakawa M, Yamamoto $T$, Kishimoto $T$, et al. Serum levels of acetate and TCA cycle intermediates during hemodialysis in relation to symptoms. Comparative study between hemodialysis with acetate dialysate versus bicarbonate dialysate. Nephron $1982 ; 32$ :155-61.

17 Kveim M, Nesbakken R. Utilization of exogenous acetate during hemodialysis. Trans Am Soc Artif Intern Organs 1975;21:138-43.

${ }^{18}$ Samar RE. Bicarbonate and acetate in haemodialysis. Contemporary Dialysis 1981; August:10-23.

19 Weiner MW. Acetate metabolism during hemodialysis. Artif Organs $1982 ; 6: 370-7$.

20 Ward RA, Wathen RL. Utilisation of bicarbonate for base repletion in hemodialysis. Artif Organs 1982;6:396-403.

21 Savdie E, Mahony JF, Stewart JH. Effect of acetate on serum lipids in maintenance hemodialysis. Trans Am Soc Artif Int Organs 1977;23: 385-92.

${ }^{22}$ Hampl H, Klopp $\mathrm{H}$, Wolfgruber $M$, et al. Advantages of bicarbonate hemodialysis. Artif Organs $1982 ; 6: 410-6$.

${ }^{23}$ Pizzarelli F, Sisca S, Zoccali C, et al. Blood temperature and cardiovascular stability in hemofiltration. Int 7 Artif Organs 1983;6:37-41.

24 Botey A, Gaya J, Montoliu J, et al. Postsynaptic adrenergic unresponsiveness in hypotensive hemodialysis patients. Proc Eur Dial Transplant Assoc $1981 ; 18: 586-91$
${ }^{25}$ Man NK, Di Giulio S, Zingraff J, Sausse A, Funck-Brentano JL. The role of sodium in the prevention of vascular instability during haemodialysis. Proc Eur Dial Transplant Assoc 1981;18:255-65.

${ }^{26}$ Kirkendol PL, Devia CJ, Bower JD, Holbert RD. A comparison of the cardiovascular effects of sodium acetate, sodium bicarbonate and other potential sources of fixed base in hemodialysate solutions. Trans Am Soc Artif Intern Organs 1977;23:399-405.

${ }^{27}$ Kirkendol PL, Robie NW, Gonzalez FM, Devia CJ. Cardiac and vascular effects of infused sodium acetate in dogs. Trans Am Soc Artif Int Organs $1978 ; 24: 714-8$.

${ }^{28}$ Keshaviah PR. The role of acetate in the etiology of symptomatic hypotension. Artif Organs 1982;6:378-84.

29 Pagel MD, Ahmad S, Vizzo JE, Scribner BH. Acetate and bicarbonate fluctuations and acetate intolerance during dialysis. Kidney Int 1982; 21 :513-8.

${ }^{30}$ Chen TS, Friedman HS, Del Monte M, Smith AJ. Hemodynamic changes during dialysis. Proc Clin Dial Transplant Forum 1979;9:66-71.

${ }^{31}$ Liang C-S, Lowenstein JM. Metabolic control of the circulation; effects of acetate and pyruvate. 7 Clin Invest 1978;62:1029-38.

${ }^{32}$ Hearse DJ, Stewart DA, Chain EB. Diabetes and the survival and recovery of the anoxic myocardium. $\mathcal{F}$ Mol Cell Cardiol 1975;7:397-415.

${ }^{33}$ Graefe U, Milutinovich J, Follette WC, Vizzo JE, Babb AL, Scribner BH. Less dialysis-induced morbidity and vascular instability with bicarbonate in dialysate. Ann Intern Med 1978;88:332-6.

34 Tolchin N, Roberts JL, Lewis EJ. Respiratory gas exchange by highefficiency hemodialysers. Nephron 1978;21:137-45.

35 Brubaker LH, Nolph KD. Mechanisms of recovery from neutropenia produced by hemodialysis. Blood $1971 ; 38: 623-31$.

${ }^{36}$ Ahmad S, Pagel M, Shen F, Vizzo J, Scribner BH. Effects of oxygen administration on the manifestation of acetate intolerance in dialysis patients. American fournal of Nephrology $1982 ; 2: 256-60$.

${ }^{37}$ Borges HF, Fryd DS, Rosa AA, Kjellstrand CM. Hypotension during acetate and bicarbonate dialysis in patients with acute renal failure. American fournal of Nephrology $1981 ; 1: 24-30$.

\section{Kielland or Caesar?}

The second stage of labour begins when the cervix is fully dilated and normally ends less than 45 minutes later $^{1}$ with delivery of the baby. The most common reasons for obstetric intervention are delay and fetal distress, but both may be diagnosed too readily. Arbitrary time limits have often been set on the second stage because of worries about fetal asphyxia and acidosis, ${ }^{2} 3$ but obstetricians now believe that timing should start only when the vertex appears at the introitus ${ }^{4}{ }^{5}$ or when pushing begins ${ }^{6}$ : full cervical dilatation alone does not endanger the fetus, and if it is diagnosed at routine vaginal examination the mother should not be encouraged to push until she feels the urge to do so.

The diagnosis of fetal distress in the second stage may also be difficult, because decelerations of the fetal heart rate are often seen even in normal babies, ${ }^{78}$ and the passage of meconium at this stage does not necessarily indicate asphyxia. ${ }^{9}$ Fetal acidosis is likely, however, when signs of fetal distress have already been seen in the first stage of labour or when decelerations and meconium appear together. ${ }^{9}$ Fetal blood sampling will resolve any uncertainty and should help to avoid unnecessary intervention. If fetal acidosis is confirmed early in the second stage caesarean section is preferable to a difficult forceps delivery. ${ }^{10}$

Midcavity arrest in the primigravid woman is often caused by uterine inertia, but the obstetrician may be reluctant to use oxytocin because of the possibility of cephalopelvic disproportion. Among multigravidas secondary arrest of labour may indeed be due to disproportion, but among primigravidas (whose risk of disproportion has been shown to be very low ${ }^{11}$ ) oxytocin may safely be used for the first time in the second stage and often produces descent and rotation of the head and a spontaneous or simple forceps delivery ${ }^{6}{ }^{12}$ Active management also reduces the incidence of occipitoposterior malposition. ${ }^{13}$ Application of these principles and the use of 
manual rotation have led to Kielland's forceps being discarded at the National Maternity Hospital, Dublin - with no increase in the caesarean section rate. ${ }^{14}$

Nevertheless, sometimes the head remains unrotated despite good contractions, and this problem seems commoner among women receiving continuous lumbar epidural analgesiawidely used in British hospitals. Epidural anaesthesia lengthens the second stage by relaxing the pelvic floor and abolishing the urge to push, ${ }^{15}$ and while its effect on the forceps rate is still debated ${ }^{16}$ one centre has reported a 20 -fold increase in forceps rotation. ${ }^{17}$ In these circumstances the obstetrician must choose between vaginal delivery (preceded by manual or instrumental rotation of the head) and caesarean section. If the head has failed to engage in the pelvis caesarean section is inevitable. Non-engagement is diagnosed by abdominal examination ( $p$ 315), but the diagnosis may be difficult-particularly for the trainee obstetrician, who may be misled by finding that the leading part is low in the vagina and may fail to appreciate the extent of caput and moulding.

Such difficulties have led to obstetricians (particularly in America) arguing that if rotation is necessary vaginal delivery should not be attempted. At first sight caesarean section seems a safer option, at least for the baby. The association between Kielland's forceps and traumatic intracranial haemorrhage has been well publicised in uncontrolled reports, ${ }^{18} 19$ and litigation $^{20}$ seems more likely if a brain damaged baby is delivered by forceps than if it is delivered by caesarean section. Damage to the maternal soft tissues and bladder is also less acceptable if inflicted by forceps than by surgery. Nevertheless, caesarean section carries risks-particularly when carried out as an emergency procedure at the end of a long labour. It increases the maternal mortality rate and the risk of postnatal complications, and it compromises future pregnancies. So far as the fetus is concerned caesarean section minimises the risk of traumatic intracranial haemorrhage, ${ }^{18}$ but the short term outcome as assessed by other indicators (p 315) is worse after caesarean section than after Kielland's forceps delivery. There is no satisfactory evidence that Kielland's forceps adversely affect the baby's long term development.

Feelings for and against Kielland's forceps are in danger of becoming entrenched (as often happens when firm data are lacking), and this may call into question the objectivity of uncontrolled reports. Controlled trials of abdominal versus vaginal delivery in midcavity arrest have been suggested ${ }^{21} 22$ but have not been carried out, perhaps because of the difficulty of standardising criteria for entry-particularly the crucial question of how deeply the head is engaged. So far the only comparison has been a retrospective survey ${ }^{23}$ of manual versus instrumental rotation before vaginal delivery: in a series of 807 cases Kielland's forceps caused no more fetal or maternal morbidity than manual rotation.

Guidelines for the management of midcavity arrest are now becoming clearer. ${ }^{10}$ Many episodes could be avoided by abandoning unnecessary time limits ${ }^{23 a}$ (p 315) and by readier use of oxytocin in the second stage among primigravidas. ${ }^{6}$ The remaining cases will then be the more difficult ones. Risks will be reduced by discarding the notion that a fetus distressed during the first stage should be rescued vaginally as soon as the cervix is fully dilated. The decision to use Kielland's forceps must be made by a senior obstetrician ${ }^{10}$ : the decision not to use them can sometimes be made over the phone but normally the senior obstetrician will have to examine the patient. A fully trained operator is essential, as is adequate analgesia, preferably by epidural or spinal block ${ }^{24}$ : pudendal block is usually inadequate $^{24}$ and general anaesthesia (which carries its own risks) should rarely be needed. A trial of forceps must be abandoned if the head seems too high when the blades are applied or if rotation and descent do not occur easily (p 315). Discarding Kielland's forceps completely seems an overreaction to their risks, and if the new guidelines are followed the instrument will in future be used less frequently but more safely.

JAMES OWEN DRIFE

Senior Lecturer in Obstetrics and Gynaecology,

University of Leicester,

Leicester LE2 7LX

${ }^{1}$ Bergsio P, Halle C. Duration of the second stage of labor. Acta Obstet Gynecol Scand 1980;59:193-6.

2 Wood C, $\mathrm{Ng} \mathrm{KH}$, Hounslow D, Benning $\mathrm{H}$. The influence of differences of birth times upon fetal condition in normal deliveries. Fournal of Obstetrics and Gynaecology of the British Commonwealth 1973;80:289-94.

${ }^{3}$ Pearson JF, Davies P. The effect of continuous lumbar epidural analgesia upon fetal acid-base status during the second stage of labour. Fournal of Obstetrics and Gynaecology of the British Commonwealth 1974;81:975-9.

${ }^{4}$ Wood C, Ng KH, Hounslow D, Benning H. Time-an important variable in normal delivery. Fournal of Obstetrics and Gynaecology of the British Commonwealth 1973;80:295-300.

${ }^{5}$ Paintin DB, Vincent F. Forceps delivery-obstetric outcome. In: Beard RW, Paintin DB, eds. Outcomes of obstetric intervention in Britain: proceedings of a scientific meeting of the Royal College of Obstetricians and Gynaecologists. London: Royal College of Obstetricians and Gynaecologists, $1981: 17-27$.

${ }^{6} \mathrm{O}$ 'Driscoll K, Meagher D. Active management of labour. Clinics in obstetrics and gynaecology. Supplement 1. London: Saunders, 1980: 35-8.

7 Bistoletti P, Lagercrantz H, Lunell N-O. Correlation of fetal heart rate patterns with umbilical artery $\mathrm{pH}$ and catecholamines during last hour of labor. Acta Obstet Gynecol Scand 1980;59:213-6.

${ }^{8}$ Katz M, Shani N, Meizner I, Insler V. Is end-stage deceleration of the fetal heart ominous ? Br f Obstet Gynaecol 1982;89:186-9.

${ }^{9}$ Meis PJ, Hobel CJ, Ureda JR. Late meconium passage in labor-a sign of fetal distress ? Obstet Gynecol 1982;59:332-5.

${ }^{10}$ Paintin DB. Mid-cavity forceps delivery. Br 7 Obstet Gynaecol 1982;89: 495-6.

${ }^{11}$ O'Driscoll K, Jackson RJA, Gallagher JT. Active management of labour and cephalopelvic disproportion. Fournal of Obstetrics and Gynaecology of the British Commonwealth 1970;77:385-9.

${ }^{12}$ Kirwan P. Oxytocin and the second stage of labour. Ir 7 Med Sci (in press).

${ }^{13}$ O'Driscoll K, Stronge JM. Active management of labour and occipitoposterior position. Aust NZ F Obstet Gynaecol 1975;15:1-4.

${ }_{14}$ National Maternity Hospital. Clinical Report for the Year 1982. Dublin: National Maternity Hospital, 1982.

${ }^{15}$ Crawford JS. The effect of epidural block on the progress of labour. In: Studd J, ed. Progress in Obstetrics and Gynaecology. Vol 2. London: Churchill Livingstone, 1982:85-93.

${ }^{16}$ Bailey PW, Howard FA. Epidural analgesia and forceps delivery: laying a bogey. Anaesthesia 1983;38:282-5.

17 Studd JWW, Crawford JS, Duignan NM, Rowbotham CJF, Hughes AO. The effect of lumbar epidural analgesia on the rate of cervical dilatation and the outcome of labour of spontaneous onset. $B r \mathcal{F}$ Obstet Gynaecol $1980 ; 87: 1015-21$.

${ }^{18}$ O'Driscoll K, Meagher D, MacDonald D, Geoghegan F. Traumatic intracranial haemorrhage in firstborn infants and delivery with obstetric forceps. Br $\mathcal{F}$ Obstet Gynaecol $1981 ; 88: 577-81$.

${ }^{19}$ Chiswick ML, James DK. Kielland's forceps: association with neonatal morbidity and mortality. $\mathrm{Br}$ Med $\mathcal{F} 1979 ; \mathrm{i}: 7-9$.

${ }^{20}$ Legal Correspondent. Professional negligence: the definitive view. $\mathrm{Br} \mathrm{Med}$ f $1981 ; 282: 156-7$.

${ }^{21}$ Anonymous. Kielland's forceps. Br Med F 1979 ;i :362-3.

${ }^{22}$ Hutchon DJR, McFadyen I. Kielland's forceps. Br Med $\mathcal{F} 1979 ; \mathrm{i}: 408$.

${ }^{23}$ Healy DL, Quinn MA, Pepperell RJ. Rotational delivery of the fetus: Kielland's forceps and two other methods compared. $\mathrm{Br} \mathcal{F}$ Obstet Gynaecol 1982;89:501-6.

23a Maresh M, Choong K-H, Beard RW. Delayed pushing with lumbar epidural analgesia in labour. Br. F Obstet Gynaecol 1983;90:623-7.

${ }^{24}$ Hutchins CJ. Spinal analgesia for instrumental delivery: a comparison with pudendal nerve block. Anaesthesia 1980;35:376-7.

\section{Correction}

\section{News on headache}

In the first paragraph of the leading article by Dr J N Blau, "News on headache" (16 July, $p$ 166) the 15th annual meeting of the American Association for the Study of Headache should have read the 25 th annual meeting. We apologise for this error. 